\title{
Survival in a Nuclear Age
}

\author{
February 17, 1984
}

The subject of Rabbi Beerman's Friday night sermon was a recurrent one: the threat of nuclear annihilation. He and George Regas, along with their close Muslim colleague Maher Hathout, had been devoted to the cause of nuclear disarmament for decades; together, they founded the Interfaith Center to Reverse the Arms Race, which was based at All Saints Church in Pasadena. The concern of disarmament advocates such as Beerman, Regas, and Hathout was heightened significantly by the election of Ronald Reagan as president in 1980. Reagan vowed to rebuild the US military and undertake an overhaul of the American nuclear arsenal. For Beerman, this was not merely a bad investment, but a choice of death over life. Summoning his characteristic prophetic wrath, he called attention to all of the suffering-poverty, illness, lack of education-that was prolonged by the billions of dollars sunk into the arms race. "Our ultimate commitment," he thundered in pointing to that race, "is not to what is humane, not to God, but to this super Moloch-in whose nuclear temple we have been prepared to sacrifice our children." He concluded by invoking the words of Holocaust survivor Samuel Pisar, which he quoted on other occasions, to the effect that true security resides not in weapons of destruction, but in caring for the wellbeing of people, and especially in educating the young.

Rabbi David Polish once wrote this: "There is a world out in space which is an exact duplicate of our own. It is populated with men and women like ourselves. They live in countries like our own. They conduct business and raise families. They live under various economies and governments, and are divided into different national, religious, and racial groups. They differ in only one respect. In each country, there is a pathological obsession with human welfare. As a result, over 
sixty percent of the national budgets are devoted to a compulsive and hysterical desire toward sheltering life from the normal ravages of human existence, which we accept more stoically. Billions of dollars are spent by governments on the conquest of disease. Over the years, nations have poured their resources into medical research and today no cancer, no vascular disease, no kidney ailments, no degenerative disease exist. Unheard of sums are spent by governments on housing. They have so tortured their fiscal policies that slums and blight are unheard of. They are so over-protective of their children that they overpay teachers, and training schools for teachers have to turn candidates away. The perverseness of these conditions reaches its greatest height in their legislation against all private charities on behalf of human welfare. The outlawing of private charity has, of course, stifled the philanthropic instincts of the people.

"There is only one exception to this restriction against private benevolence. Since the national budgets are so swollen with welfare appropriations, there is little left for national defense. It therefore becomes necessary for private citizens to raise money for armaments. Thousands of private organizations exist with this purpose alone. There are clubs to buy [guns] ${ }^{1}$ through raffles. People stand with tin cups on street corners to collect coins for the purchase of hand grenades. Drives are conducted to acquire submarines. There are tag days for military aircraft. Charities sponsor dances to buy uniforms. The national government simply neglects the problems of defense, and lets the burden fall on private agencies. But the inadequacy of this system is apparent to all. People are grumbling that under such conditions, there can never be another war."

Like peddlers with packs on their backs, wherever Jews go, they carry an assortment of notions, ideals. Many of them are very old, and they have found their way into the very being of all that is held to be precious in this beloved country of ours and even in civilization itself. Some, like the belief in the possibilities of human compassion and peace, are battered and tired and worn. Others, since they come out of a people that has had such a long history, have to do with history itself, and history meditated upon can be very solemn and very haunting.

I do not like this idea (an idea about which Robert Sinai has so chillingly written), yet it haunts me more than I wish. It is this, history teaches, if nothing else, that every civilization has perished sooner or later. Human social systems with their human beings anxious, insecure, swollen with pride, driven by the will to power, corrupted by self-intoxication and self-deception, sooner or later sin against the laws of proportion and harmony and plunge into decay and self-destruction. Every civilization in human history has made such a fatal error.

Now our civilization may be in the process of making the same mistake. We have been so infused with the conceit that we could escape the remorseless fate that has overtaken all previous social systems, that we with our science and industry, our democracy, our ingenuity, could violate what appears to be an iron law of history. The arms race has doomed us to nuclear insanity. Technological processes 
have committed the United States and the USSR to collective mechanisms of destruction so gross that they defy our imaginations. Our nations have become vast armories, and we are now both engaged in enlarging our capacity to destroy one another. Pre-empting every other human purpose, the nuclear arms race in all of its arrogant compulsions imposes on a world of hungry, tormented people; imposes on a world where 700 million adults are illiterate, 500 million children do not go to school, 500 million suffer malnutrition; imposes on such a world more than 700 billion dollars worth of weaponry every year. For the sake of protecting their nations, the leaders of the United States and the Soviet Union have been brazenly prepared to sacrifice more than 100 million of their citizens on the first day of an all-out nuclear war.

So we are now in a position of asymmetrical nuclear parity: We, with our 9,500 strategic nuclear warheads; the Soviet Union with their 8,000; 50,000 in all types of nuclear weapons. And now, under the Reagan budget, a one and one-half trillion dollar expenditure over a five-year period has been approved, and the building of 17,000 additional nuclear weapons over the next ten years. A billion dollars a day, almost a million a minute.

You and I have permitted this to happen. We have permitted the so-called specialists in defense to set the priorities for our country and the world. We have permitted them to enmesh us all in the cycle of design, production, and obsolescence, enlarging their power, the power of the military industrial colossus over our lives.

And we pay a terrible price for that. President Eisenhower recognized that when he said years ago: "Every gun made, every warship launched, every rocket fired, signifies a theft from those who hunger and are not fed, those who are cold and not clothed."

Isn't it a perversion of everything that is morally precious in our religious tradition to permit the military to set the priorities for our country and the world? How can we pursue human goals, how can we reckon with the decay of our cities, how can we care for the poor and the hungry and the abandoned, how can we pretend to revere the dignity that is present in every human being, when our ultimate commitment is not to what is humane, not to God, but to this super Moloch-in whose nuclear temple we have been prepared to sacrifice our children?

This is the greatest threat to our life, to the life of the human race. This is the greatest social, political, economic, environmental, theological religious Jewish issue confronting us today. This is what we must set ourselves against, if we are truly Jews dedicated to the ideals of our tradition. This is why we must become a part of a developing religious voice in the land, the constituency of those who insist on reversing the nuclear arms race. How can we erect a religious commitment on a foundation of the believable threat to kill a hundred million of God's children?

Nothing is as hard to overcome as the will to be enslaved to our own moral inertia. Yet we know there is another power within us, the power of our own decency, our own critical intelligence, the power of the human spirit, a spiritual 
power present in every person-and it can be actualized. We shall have to actualize this power without pretending away our need for security, or that we do indeed live in a world brimming with anger and suspicion, inertia and adversaries.

There is a story members of the clergy like to tell. It concerns a minister or priest or rabbi who wanted to stage an object lesson for the members of the congregation, so the cleric places a lion and lamb in a cage just outside the entrance of his church. And they lived together in peace. And people came from miles around to see this remarkable phenomenon. Finally, the governor of the state, intrigued by this remarkable feat, sent a delegation to inquire how the minister pulled off the trick. "Oh, there's no trick at all," said the minister. "All you have to do is put in a fresh lamb from time to time."

In the real world, we know very well, lions and lambs do not live together peacefully. Even the prophet Isaiah, when he spoke of such a possibility, was referring to a time in the distant future, a messianic time. And that's where the rub is for us: How to face up to the truth of this real world of brutality, fear, mutual rivalry, the need for security, and still retain hope, still work for something different, work to reverse the arms race, work to retain our faith in human destiny, and still maintain a firm conviction that we can (to use Neruda's words) "approach a great common tenderness." We must not let this hope be crushed amidst the powers and principalities.

Let hope give us the courage to say "No" to all those mighty forces that would condemn us to the continuing despair of the waste and perversion of all that affirms the humane, the intelligent, and the tender that is within us.

In June of 1981, 6,000 Jews gathered in Jerusalem at a conference of survivors of the Holocaust, gathered to perpetuate the memory of the victims in a world whose memory is fading. They recalled their nightmares, remembering how their world was destroyed, and attempted to draw insights into how their children's world could be preserved. Speaking before members of Israel's Knesset, survivor of Auschwitz, world-renowned lawyer Samuel Pisar had this to say:

"We have a unique legacy to hand down to our fellowmen, Jews and non-Jews alike, especially to the young, because our message of blood and hope is not about the past but about the future ... we must help save them from tragedy ... We must impress upon them the true meaning of the dangers pushing mankind to a new Holocaust . . . For us, the Holocaust is not just a terrible memory that will never be erased, it is a constant warning. We feel in our bones the fear and the growing fury lurking in the roots of seething international disputes, which diplomats, economists, and politicians discuss with such dry indifference . . . For we saw at Auschwitz a model for destroying the human species. We are the ones who know that the unthinkable can happen ... We have a duty to reaffirm, in this place and at this time, the primordial importance of the great values of Judaism in the continued quest for survival and peace. 
"Here with the authority of the numbers engraved on our arms, we cry out the commandment of six million innocent souls, including one and a half million children: Never again! From where, if not from us, will come the warning that a new combination of technology and brutality can transform the planet into a crematorium? From where, if not from the bloodiest killing-ground of all time, will come the hope that co-existence between . . . enemies is possible. From where, if not from the slaughterhouses of World War II, will come the lesson that true security cannot lie much longer in defendable borders and powerful arms alone, but in a fundamental reassessment of the common perils and needs of adversaries who must drown their passions in a joint enterprise of economic, cultural and human development, and ultimately in the minds and schoolbooks of children?"

The earth is too small and life too short for anything to be more important than the quest for peace.

\section{COMMENTARY BY THE REVEREND GEORGE F. REGAS}

Leonard and I met in 1967 at a peace rally against the Vietnam War, and became the best of friends, a rabbi and an Episcopal priest, who traveled the world together in search of peace. Our different faith commitments drew us closer rather than separated us. I like to think that our friendship was a gift given to us so we could sustain each other in the hard, controversial work of peace in a hostile world.

The danger of unbelievable disaster in the escalating nuclear arms race was a threat that Leonard and I felt we must address. Leonard had incredible vision, and was always full of hope that we could create a more just and peaceful world. We wanted to call together leaders of the religious community of Los Angeles and ignite them with a moral passion for stopping the mad momentum of the arms race that was whirling us toward destruction.

In response, Leo Baeck Temple and All Saints Church jointly sponsored a major conference on reversing the arms race in October of 1979, which was attended by 1,00o people. From the success of this event, the Interfaith Center to Reverse the Arms Race was born. Over the ten years that we sustained it, the center grew significantly, involving many clergy and congregations in our mission, and included our first collaboration with the Muslim community. Our goal was to see the religious community become a powerful lobby for peace. 